\title{
Influence of Ultraviolet Light and Ultrasound Irradiation on the Physicochemical, Sensory and Microbiological Characteristics of Pear Jam Enriched with Fibers
}

\author{
Zdravko Manev 1,*(D), Nadezhda Petkova ${ }^{2, *(D)}$ \\ 1 Institute of Food Preservation and Quality, Vasil Aprilov Blvd. 154, 4003 Plovdiv, Bulgaria, z.manev44@gmail.com \\ (Z.M.); \\ 2 Department of Organic Chemistry and Inorganic Chemistry, Technological Faculty, University of Food Technologies, 26 \\ Maritsa Blvd., 4002 Plovdiv, Bulgaria; petkovanadejda@abv.bg (N.P.); \\ * Correspondence: z.manev44@gmail.com; (Z.M.); petkovanadejda@abv.bg (N.P.);
}

Received: 1.02.2021; Revised: 1.03.2021; Accepted: 3.03.2021; Published: 9.03.2021

\begin{abstract}
The ultraviolet light and ultrasound irradiation present a green approach to non-thermal conservation in food processing. This research aimed to investigate the effect of ultraviolet light and ultrasound irradiation on the fiber-enriched pear fruit jam's physicochemical properties, sensory profile, and microbiological characteristics. The moisture, ash, $\mathrm{pH}$, titrable acidity, sugar content, energy value, heavy metals were determined in the samples. The sensory and microbiological characteristics were also evaluated in pear jams. It was found that the treatment of ultraviolet light and ultrasound irradiation caused minimal changes in $\mathrm{pH}$, titrable acidity, dry matter, and sucrose content. The sensory characteristics (color, odor, and taste) also did not alter significantly during treatment with ultraviolet light and ultrasound irradiation. The values of other sensory characteristics as graininess, elasticity, and juiciness showed better acceptance for jam treated with ultrasound irradiation. The pear jam's lowest microbial growth level was observed after ultraviolet light and ultrasonic irradiations for 10 minutes in polypropylene packaging and 15 minutes in glass packaging, respectively. However, ultrasonic irradiation demonstrated a more effective overall bactericidal effect in polypropylene packaging, while ultraviolet light showed better results in a glass packaging pear jam.
\end{abstract}

Keywords: pear jam; physicochemical characteristics; sensory evaluation; microbiological safety.

(C) 2021 by the authors. This article is an open-access article distributed under the terms and conditions of the Creative Commons Attribution (CC BY) license (https://creativecommons.org/licenses/by/4.0/).

\section{Introduction}

Fruit jam is a semi-solid food product prepared by boiling fruit pulp at a temperature of 95-100 ${ }^{\circ} \mathrm{C}$. Jam can be made from fresh, frozen, chilled, sulfited, or dried fruits. The whole fruit or pulp processing into jam leads to changes in color, texture, and volatile profile [1-3].

The use of ultraviolet light is an innovative non-thermal technology for minimal food processing that improves food safety, nutrient content, appearance and extends the shelf life of products $[4,5]$. The application of ultraviolet light can be an alternative method to thermal processes that can decrease pathogenic microorganisms in food [6]. Short wave ultraviolet light (UV-C) has some advantages over other non-thermal methods, such as the absence of toxic residues, low energy consumption, and low operating costs [7]. According to some authors, the use of shortwave ultraviolet light (UV-C) leads to minimal changes in the nutritional and quality characteristics and significant inactivation of pathogenic microorganisms in some liquid foods such as carambola watermelon and pomegranate juice [8-10]. However, the 
treatment with ultraviolet light can adversely affect the composition of food because several harmful photochemical reactions can be activated after the formation of free radicals, which can decrease the number of valuable nutrients [11]. It has been found that treatment with ultraviolet light can change the taste of citrus fruits, reduce the content of carotene, as well as reduce the content of vitamins $\mathrm{A}$ and $\mathrm{C}$ in all fruits and vegetable juices [12], especially vitamin $\mathrm{C}$ in apple and carrot juice, from 30 to $40 \%$ and from 18 to $25 \%$, respectively [13]. However, after irradiation of mango juice with ultraviolet light (UV-C) for a period of 15 to 60 minutes, no significant change in physicochemical parameters - $\mathrm{pH}$, total soluble solids (Brix), and titratable acidity [14]. Moreover, most food products' physicochemical and sensory properties remain almost unchanged after treatment with ultraviolet light in reasonable doses [15]. Besides, treatment with ultraviolet light results in minimal loss of the food's nutritional and sensory quality and does not result in any toxic effects or residues associated with ultraviolet treatment [16].

Another approach is the application of ultrasonic irradiation. Ultrasound treatment is one of the many non-thermal techniques for preserving food products such as fruit juices. Experiments have shown that ultrasound inhibits microorganisms' growth and inactivates enzymes in orange and red grape juice [17]. The use of ultrasonic power in food technology can improve reaction conditions by lowering the temperature and reducing the processing time [18]. The use of ultrasonic processing with high intensity and low frequency $(16-100 \mathrm{kHz})$ generates mechanical acoustic waves, which generate oscillating cycles of compression and dilution in a liquid medium. During these compression cycles, the gas bubbles that are initially present in the liquid medium grow, leading to critical size and collapse, i.e., cavitation [19]. It was found that ultrasound treatment did not significantly affect physicochemical parameters $\mathrm{pH}$ and total soluble solids in fruit puree of physalis [20]. The increasing duration of ultrasonic treatment on syrup caused a minimal reduction in active acidity $(\mathrm{pH})$, total soluble solids, and the absence of statistically significant changes in titratable acidity [21]. The increase in sucrose content was detected after ultrasound irradiation in the cantaloupe juice and a syrup composed of pine honey, apple cider vinegar, and sterilized water [21,22]. This could be explained by an increase in the efficiency of extraction by ultrasonic treatment, destroying plant tissues and cell walls. As a result, more water enters the cells, and more soluble solids can penetrate through the cell membranes [23].

Until now, the investigation on the effect of ultrasonic waves and ultraviolet light as a non-thermal approach for conservation on peach jam enriched with fibers is limited. Its application has a beneficial effect on food structure and improves the health stats of products. Dietary fiber prevents syneresis, improves the structure and sensory properties of food [24], can reduce the energy density of foods [25], lowers blood glucose and cholesterol levels, as well as protecting against colon cancer [26].

The present study aimed to investigate the effect of ultraviolet light and ultrasound irradiation on the physicochemical properties, sensory profile, and microbiological characteristics of fiber-enriched pear fruit jam.

\section{Materials and Methods}

\subsection{Production of fruit jam from pears enriched with fiber.}

Cellulose fibers $(15.0 \mathrm{~g})$ were mixed with aspartame $(0.60 \mathrm{~g})$, potassium sorbate $(0.27$ $\mathrm{g}), 340.0 \mathrm{~g}$ of pear pulp (56.6\% from variety Santa Maria) in a $1000 \mathrm{ml}$ beaker, and then $600 \mathrm{~g}$ 
distilled water was added. The mixture was stirred and boiled to $10 \%$ Brix. Then a mixture of $6.0 \mathrm{~g}$ of slow-gelling sodium alginate and $4.80 \mathrm{~g}$ of low-esterified amidated pectin was added, and the residue was washed with 20-30 $\mathrm{g}$ of distilled water and stirred. The sample was concentrated to $12 \%$ Brix. The losses from water evaporation are $16.87 \%$. The gelling process was performed by adding $7 \%$ calcium lactate pentahydrate for 20 hours at room temperature. The pear jam was then dried on kitchen paper to remove excess calcium salt that was not included in jelly formation. According to Regulation №1924/2006 [27], the pear jam obtained before the technological treatment with ultraviolet light and ultrasound is a low-energy product $(35.86 \mathrm{kcal})$ and a source of fiber $(4.94 \%)$.

\subsection{Technological processing of fruit jam from pears.}

The type and time of technological processing of fruit jam from pears were selected based on the maximum degree of preservation of biologically active components (antioxidants and total phenols) compared to the control based on our unpublished research. The smallest degree of reduction of structural-mechanical values related to the final product's strength was identified in a previous study [28]. Ultraviolet treatment of the product was performed using an ultraviolet sterilizer - Towel Warmer model: JY-502 with a power of 200W. The produced pear jam was irradiated with ultraviolet light with a wavelength of $254 \mathrm{~nm}$ (UV-C) without heating for 10 minutes. The ultrasonic irradiation (US) of the fruit jam was done in an ultrasonic bath - Siel Gabrovo UST 5.7-150 with a power of 300W with a $36 \mathrm{kHz}$ frequency for 20 minutes. In the technological processing of the obtained pear jam enriched with cellulose fibers, transparent colorless glass packages were used.

\subsection{Physicochemical analysis of pear jam.}

Active acidity (pH) was determined according to ISO 750:1998(E). [29]. Titratable acidity was evaluated by the titration method with $0.1 \mathrm{M} \mathrm{NaOH}$ [30]. Dry matter and moisture were determined by drying the sample to the constant weight at $105^{\circ} \mathrm{C}$ [31]. The total ash was evaluated by igniting the sample in a muffle furnace at $550{ }^{\circ} \mathrm{C}$ [32]. The HPLC-RID method evaluated the sucrose content with a flow rate of $1.0 \mathrm{ml} / \mathrm{min}$ [33]. Total reducing sugars were evaluated by the spectrophotometric method [33]. Determination of the energy value of pear jam was performed according to BDS ISO 1871: 2014; BDS 5439: 1985. and Regulation № 1169 of $2011[34,35]$.

\subsection{Determination of metals in pear fruit jam.}

All heavy metals were determined in the laboratory - Pisanets, Plovdiv, Republic of Bulgaria. The values of heavy metals (copper, zinc, lead, cadmium, and chromium) determined using colorimetric validated methods (VLM 034-copper, VLM 035-zinc, VLM 032 - lead, VLM 033-cadmium, VLM 038 - chromium) according to EN ISO 11885 [36].

\subsection{Sensory evaluation.}

Sensory evaluation of pear fruit jam was performed by applying sensory descriptive analysis according to ISO 6658: 2017 [26]. A panel performed the sensory analysis consisted of 7 previously taught panelists ( 3 men and 4 women) aged between 33 to 56 years from the Department - Food Technology at the Institute of Food Canning and Quality - Plovdiv, Bulgaria. The panelists evaluated two fruit jam samples from pears enriched with fiber but with 
different technological processing - irradiation with ultraviolet light and ultrasound, respectively. The product's evaluation comprised certain sensory characteristics: appearance, aroma, taste, aftertaste, and texture. The evaluation of the samples was done by using a 10point scale (1-10), where 9-10 = excellent; 7-8 = very good; 5-6 = good; $3-4=$ average; $1-2=$ poor/unacceptable [37]. The more pronounced a given sensory characteristic of the pear jam, the higher the rating was obtained.

\subsection{Microbiological analysis.}

To evaluate the microbiological safety of pear fruit jam, molds, yeasts, and a total number of mesophilic aerobic and facultative anaerobic bacteria have been identified. Microbial contamination was determined based on technological treatment's influence with ultraviolet light and ultrasound simultaneously (10, 15, and 20 minutes, respectively) and the type of packaging (polypropylene packaging and glass jars). The studied species of microorganisms were evaluated using the following standard methods: BNS EN ISO 215272:2011 [38] (for molds and yeasts) and EN ISO 4833-1:2013 [39] (for a total number of mesophilic aerobic and facultative anaerobic bacteria).

\subsection{Statistical analysis.}

The values obtained from analyzes were performed and processed with MS Excel 2007 software. The statistical significance of the results was determined by Fisher's test (F-Test TwoSimple for Variances) to test the hypothesis of equality in variances confidence level $\alpha=0.05$ $(\mathrm{p}<0.05)$.

\section{Results and Discussion}

\subsection{Physicochemical analysis of pear jam.}

The results from the different treatments of pear jam on its physicochemical properties were summarized in Table 1.

Table 1. Physicochemical analysis of pear jam.

\begin{tabular}{|c|c|c|c|}
\hline \multirow{4}{*}{ Physicochemical characteristics } & \multicolumn{3}{|c|}{ Type of treatment } \\
\hline & Control & Ultraviolet & Ultrasound \\
\hline & \multicolumn{3}{|c|}{ Sample № } \\
\hline & P00 & P01 & P02 \\
\hline Active acidity $(\mathrm{pH})$ & $4.84 * \pm 0.20^{\mathrm{a}}$ & $4.89^{*} \pm 0.20^{\mathrm{a}}$ & $4.87 * \pm 0.20^{\mathrm{a}}$ \\
\hline Titratable acidity (expressed as citric acid \%) & $0.20 \pm 0.01^{\mathrm{a}}$ & $0.19 \pm 0.01^{\mathrm{a}}$ & $0.19 \pm 0.01^{\mathrm{a}}$ \\
\hline Dry matter $(\%)$ & $13.10 \pm 0.66^{\mathrm{a}}$ & $12.96 \pm 0.66^{\mathrm{a}}$ & $13.30 \pm 0.66^{\mathrm{a}}$ \\
\hline Moisture content $(\%)$ & $86.90 \pm 0.66^{\mathrm{a}}$ & $87.04 \pm 0.66^{\mathrm{a}}$ & $86.70 \pm 0.66^{\mathrm{a}}$ \\
\hline Ash (\%) & $0.90 \pm 0.05^{\mathrm{a}}$ & $1.01 \pm 0.05^{\mathrm{a}}$ & $0.92 \pm 0.05^{\mathrm{a}}$ \\
\hline Sucrose $(\%)$ & $0.70 \pm 0.05^{\mathrm{a}}$ & $1.07 \pm 0.05^{\mathrm{a}}$ & $1.66 \pm 0.05^{\mathrm{a}}$ \\
\hline Total sugars $(\%)$ & $3.14 \pm 0.10^{\mathrm{a}}$ & $2.65 \pm 0.10^{\mathrm{a}}$ & $2.27 \pm 0.10^{\mathrm{a}}$ \\
\hline Energy value $(\mathrm{kcal} / 100 \mathrm{~g})$ & $39.13 \pm 2.00^{\mathrm{a}}$ & $37.61 \pm 2.05^{\mathrm{a}}$ & $40.09 \pm 2,00^{\mathrm{a}}$ \\
\hline
\end{tabular}

* Mean of three measurements $(\mathrm{n}=3) \pm$ standard deviation. The values followed by the same letters in each line are not statistically significant $(\mathrm{p}>0.05)$ according to the F-test

Minimal changes in $\mathrm{pH}$ values and titratable acidity were observed in both non-thermal treatment methods compared to the control sample. It has been scientifically proven that minor changes in $\mathrm{pH}$ may be due to the lack of heat from ultraviolet radiation, the period of application of ultrasound is not sufficient to lead to disruption of chemical bonds in the molecular structures of nutrients in liquid foods $[21,40]$ or due to the component composition of organic acids and 
polyphenols in the products [41]. The ultrasonic treatment (300W power) of the fruit jam for 20 minutes led to a slight increase in $\mathrm{pH}$ compared to the control sample (Table 1). A similar $\mathrm{pH}$ effect after ultrasonic irradiation (frequency $20 \mathrm{kHz}$; duration $20 \mathrm{~min}$ and power-300W) was reported in myofibrillar proteins [42].

The titratable acidity indicates the content of organic acids in the samples, and it is an important feature for taste and overall acceptance of the product, especially in some jams as strawberry jellies [43] and orange fruit jam [44]. The results (Table 1) showed a minimal reduction of the titratable acidity compared to the control sample. No statistically significant difference in titratable acidity was found between the individual samples (P01 and P02) in both non-thermal treatment methods on pear jam. A similar effect of ultraviolet light and ultrasound on titratable acidity was found in mango juice [14] and passion fruit juice [45].

Experiments have shown that the treatment with ultraviolet light and ultrasound possessed a negligible effect on dry matter content and moisture in pear jam (Table 1). It can be seen that the ultrasonic treatment on the jam led to minimal losses in dry matter content compared to the control. A similar effect was found in the treatment of apple tissue with ultrasound with a frequency of $40 \mathrm{kHz}$ and a power of 180W [46]. The dry matter content of this pear fruit jam (with a fruit content of $68 \%$ in the final product) is slightly more than three times less than the commercial fruit apricot jam with a fruit content of $60 \%$ [47]. It has been found that the dry matter in most commercial fruit jams varies in the range of $40 \%$ to $70 \%$, and in home-made jams, it was in the wide range of $20 \%$ to $70 \%$ [47].

It can be noticed that in the sample irradiated with ultraviolet light, the ash content increased to a slightly greater extent compared to the ultrasonic treatment compared to the control (Table 1). A similar increase in mineral composition compared to the control after treatment with ultraviolet light was found in African amaranth and apples [48,49]. The ash content represents the amount of minerals such as calcium, phosphorus, and iron present in the sample, and the value of the ash content indicates the stability of the product [50].

Fruits contain mainly sugars (sucrose, glucose, and fructose) and other carbohydrates in various amounts, and their content directly affects the fruit quality and taste [51]. According to some authors, changes in sugars' ratio can lead to fruit taste changes and hardness [52]. The results (Table 1) showed that the ultraviolet light treatment led to a minimal increase in sucrose content and reduced the total sugars. Similar effects of ultraviolet light were reported during storage of pear juice variety - Blanquilla [53]. The reduction in the total sugar content compared to controls may be because sugars (glucose, fructose, and sucrose) have high ultraviolet absorption in the range of 240 to $360 \mathrm{~nm}$ and fructose from 260 to $280 \mathrm{~nm}$, which can lead to significant amounts of fructose losses in fruit juices after treatment with ultraviolet light [54]. Ultrasound treatment resulted in an increase of sucrose content compared to the control. A similar effect was found in pear juice's ultrasonic treatment at a $25 \mathrm{kHz}$ frequency for 45 and 60 minutes [55]. According to some studies, sugars are involved in polyphenols' biosynthesis, and thus the high sugar content in fruits implies a higher content of polyphenols [56]. The increase in sucrose content during ultrasonic treatment may be due to the rupture of plant cells by the shear force caused by the mechanical effect of ultrasound, which in turn improves the diffusion rate of the solvent from the material to the solvent, leading to extraction of intracellular sugars [57].

The results in Table 1 showed that the energy value of P01 is lower and that of P02 was higher than P00. This fact is most likely due to the different effects of ultraviolet light and ultrasound on the content of sucrose and total sugars. The obtained energy value of P01 and 
P02 was twice lower than mixed fruit jam enriched with 12\% mulberry leaves [58] and three times lower compared to jam made with velvety tamarind pulp [59]. According to Regulation №1924/2006, the pear jam obtained is low -caloric and without added sugars.

\subsection{Metal content in pear jam.}

No significant differences ( $p>0.05)$ were observed between the values for the content of all heavy metals of the fruit jam treated with ultraviolet light and ultrasound compared to the control (Table 2). The copper and zinc content in this pear jam were 1.8 and 3.8 times lower than strawberry fruit jam, respectively, and the lead concentration is often lower than mango and pineapple fruit jam [60].

Table 2. Metal content in pear jam $(\mathrm{mg} / \mathrm{kg})$.

\begin{tabular}{l|l|l|l|l|l} 
Sample & Copper $(\mathrm{Cu})$ & Zinc $(\mathbf{Z n})$ & Lead $(\mathrm{Pb})$ & Cadmium $(\mathbf{C d})$ & Chromium $(\mathrm{Cr})$ \\
\hline P00* & $<0.50^{\mathrm{a}}$ & $<2.00 \mathrm{a}$ & $<0.08 \mathrm{a}$ & $<0.05 \mathrm{a}$ & $<0.50 \mathrm{a}$ \\
\hline P01** & $<0.50^{\mathrm{a}}$ & $<2.00 \mathrm{a}$ & $<0.08 \mathrm{a}$ & $<0.05 \mathrm{a}$ & $<0.50 \mathrm{a}$ \\
\hline P02*** & $<0.50^{\mathrm{a}}$ & $<2.00 \mathrm{a}$ & $<0.08 \mathrm{a}$ & $<0.05 \mathrm{a}$ & $<0.50 \mathrm{a}$
\end{tabular}

* P00 - control sample; **P01 - pear jam treated with ultraviolet light; ***P02 - pear jam treated with ultrasonic irradiation, the values followed by the same letters in each line are not statistically significant ( $>0.05$ ) according to the F-test.

The determined content of copper and zinc in pear jam was close to apricot jam value with a fruit pulp content of $87.04 \%$ from Egypt [61]. The values obtained from cadmium and chromium content in pear jam were twice lower than in fruit jam [62]. Lead and cadmium were not detected in figs, quinces, strawberries, and apricot jams [61].

\subsection{Sensory evaluation.}

There are minimal differences between the panel's evaluations for all types of sensory characteristics in the treatment with ultraviolet light and ultrasound (Table 3). The sensory analysis revealed insignificant differences in the color and smell of pear fruit jam.

Table 3. Sensory evaluation of pear jam.

\begin{tabular}{l|l|l}
\multirow{2}{*}{ Sensory evaluation } & \multicolumn{2}{c}{ Sample } \\
\cline { 2 - 3 } & $\begin{array}{l}\text { Pear jam treated with } \\
\text { ultraviolet light }\end{array}$ & $\begin{array}{l}\text { Pear jam treated with } \\
\text { ultrasonic irradiation }\end{array}$ \\
\hline \multicolumn{3}{c}{ Appearance } \\
\hline Colour & \multicolumn{1}{c}{ Odor } & $7.14^{*} \pm 2.12 \mathrm{a} .27 \mathrm{a}$ \\
\hline \multicolumn{3}{c}{ Taste } \\
\hline Specific for jam & $7.29 \pm 1.60 \mathrm{a}$ & $7.43 \pm 2.15 \mathrm{a}$ \\
\hline Sweet taste & $7.29 \pm 2.75 \mathrm{a}$ & $7.43 \pm 2.57 \mathrm{a}$ \\
\hline Sour taste & $3.14 \pm 2.97 \mathrm{a}$ & $3.86 \pm 3.44 \mathrm{a}$ \\
\hline \multicolumn{3}{c}{ Aftertaste } \\
\hline Sweet taste & $7.00 \pm 2.45 \mathrm{a}$ & $7.29 \pm 2.75 \mathrm{a}$ \\
\hline Sour taste & $4.29 \pm 2.81 \mathrm{a}$ & $5.00 \pm 3.16 \mathrm{a}$ \\
\hline \multicolumn{3}{c}{ Texture/Consistency } \\
\hline Hardness & $7.57 \pm 1.72 \mathrm{a}$ & $7.43 \pm 1.27 \mathrm{a}$ \\
\hline Grain structure & $5.57 \pm 3.05 \mathrm{a}$ & $6.00^{*} \pm 3.42 \mathrm{a}$ \\
\hline Elasticity/chewability & $6.71 \pm 1.98 \mathrm{a}$ & $7.43 \pm 2.15 \mathrm{a}$ \\
\hline Juiciness & $7.00 \pm 2.16 \mathrm{a}$ & $7.57 \pm 1.90 \mathrm{a}$
\end{tabular}

*Mean of seven measurements $(n=7) \pm$ standard deviation. The values followed by some and the same letters in each line are not statistically significant $(\mathrm{p}>0.05)$ according to the F-test.

Similar minimal and insignificant color and odor differences were reported in a jam with 6.5\% Hibiscus sabdariffa extract and mixed papaya and mango jam [62]. Regardless of 
the method of processing (ultraviolet light or ultrasound), it was noticed that the sweet taste and aftertaste have a stronger intensity (there are higher grades) compared to the sour taste and aftertaste in the final product. This is since a sweet-sour taste characterizes the varieties of pears from which the fruit jam is made. On the other hand, the sweet taste is further enhanced by the evaporation of a part of the water content during the jam's boiling and the added sweetener (aspartame). Regarding the sensory indicators constituting the pear jam's texture, no significant differences were found in the treatment with ultraviolet light and ultrasound. From the estimates presented in Table 3, the fruit jam's hardness (when treated with UV-C) has a higher value than ultrasound. This effect is because ultraviolet light decreases in some rheological parameters (hardness and fragility) in freshly cut pears [63]. The other sensory characteristics - graininess, elasticity, and juiciness in ultrasonic treatment have slightly higher scores than ultraviolet treatment. This effect is because high-frequency ultrasound with high power can lead to better maintenance of fruit pulps' initial quality in pears, apples and strawberries, and bilberry [64].

\subsection{Microbiological studies.}

The influence of different treatments and types of packaging on the jam samples for the total number of mesophilic aerobic and facultative anaerobic bacteria, molds, and yeasts were summarized (Table 4). The increase of time of the ultraviolet radiation did not cause such a high degree of sterility compared to the control sample in polypropylene packaging and glass packaging.

Table 4. Level of microbial contamination of fruit jam in polypropylene packaging and glass bottle packaging.

\begin{tabular}{|c|c|c|c|c|c|c|c|}
\hline \multirow[t]{2}{*}{ Sample } & \multirow[t]{2}{*}{$\begin{array}{l}\text { Type of } \\
\text { treatment/Time, } \\
\text { min }\end{array}$} & \multicolumn{2}{|c|}{$\begin{array}{c}\text { Total number of } \\
\text { mesophilic aerobic and } \\
\text { facultative anaerobic } \\
\text { bacteria (Cfu/g) }\end{array}$} & \multicolumn{2}{|c|}{$\begin{array}{l}\text { Mold } \\
\text { (Cfu/g) }\end{array}$} & \multicolumn{2}{|c|}{$\begin{array}{l}\text { Yeasts } \\
(\mathrm{Cfu} / \mathrm{g})\end{array}$} \\
\hline & & $\begin{array}{l}\text { polypropylene } \\
\text { packaging }\end{array}$ & $\begin{array}{l}\text { glass } \\
\text { packaging }\end{array}$ & $\begin{array}{l}\text { polypropylene } \\
\text { packaging }\end{array}$ & $\begin{array}{l}\text { glass } \\
\text { packaging }\end{array}$ & $\begin{array}{l}\text { polypropylene } \\
\text { packaging }\end{array}$ & $\begin{array}{l}\text { glass } \\
\text { packaging }\end{array}$ \\
\hline 1 & $\begin{array}{l}\text { - Control sample } \\
\text { before } \\
\text { thermostating }\end{array}$ & 20 & 10 & $<10$ & $<10$ & $<10$ & $<10$ \\
\hline 2 & $\begin{array}{l}\text { - Control sample } \\
\text { after } \\
\text { thermostating at } \\
30^{\circ} \mathrm{C} / 48 \text { hours }\end{array}$ & $8,9.10^{3}$ & 20 & $4,9.10^{4}$ & $<10$ & $<10$ & $<10$ \\
\hline 3 & $\begin{array}{l}\text { Ultraviolet/10 } \\
\min \end{array}$ & $<10$ & 20 & $<10$ & $<10$ & $<10$ & $<10$ \\
\hline 4 & $\begin{array}{l}\text { Ultraviolet/15 } \\
\text { min }\end{array}$ & $1,41.10^{4}$ & $<10$ & $2,32.10^{5}$ & $<10$ & $<10$ & $<10$ \\
\hline 5 & $\begin{array}{l}\text { Ultraviolet/20 } \\
\text { min }\end{array}$ & $6,7.10^{3}$ & $<10$ & $4,4.10^{4}$ & $<10$ & $<10$ & $<10$ \\
\hline 6 & $\begin{array}{l}\text { Ultrasound/10 } \\
\text { min }\end{array}$ & $<10$ & 190 & $<10$ & $<10$ & $<10$ & $<10$ \\
\hline 7 & $\begin{array}{l}\text { Ultrasound/15 } \\
\text { min }\end{array}$ & 10 & 90 & $<10$ & $<10$ & $<10$ & $<10$ \\
\hline 8 & $\begin{array}{l}\text { Ultrasound } / 20 \\
\min \end{array}$ & $<10$ & 490 & $<10$ & $<10$ & $<10$ & $<10$ \\
\hline
\end{tabular}

This could be explained by the fact that the polypropylene packaging reduces ultraviolet light's transmittance, while the glass packaging does not reduce it. The transmittance of ultraviolet light in the polypropylene packages with a thickness of $50 \mu \mathrm{m}$ is only $64 \%$ [65]. The bactericidal effect of ultraviolet light can cause less microbial destruction when used on opaque foods with an uneven surface [66]. This additional fact leads to a reduction in part of the efficiency of ultraviolet light. A low degree of microbial contamination of all types of tested 
microorganisms compared to the control was observed when irradiated with ultraviolet light with a wavelength of $254 \mathrm{~nm}$ for 10 minutes using the polypropylene packaging (Table 4). According to some studies, ultraviolet light with a $254 \mathrm{~nm}$ wavelength has the highest bactericidal effect [67]. It has been scientifically proven that ultraviolet light with a wavelength of 100 to $280 \mathrm{~nm}$ (UV-C) is a useful tool for inactivating bacteria (including spores), molds, yeasts, viruses, and markets [68]. Microbiological studies have shown that by increasing ultraviolet radiation time over 10 minutes using polypropylene packaging, the total number of mesophilic bacteria on pear jam was not significantly reduced (Table 4). A similar effect associated with a slight change in the total number of surviving mesophilic bacteria was observed when irradiated with ultraviolet light for more than 12 minutes on fresh apricots [69]. Prolonged irradiation with ultraviolet light (over $10 \mathrm{~min}$.) does not reduce the degree of microbial contamination of the molds, and the growth and development of yeast were completely inhibited in the comparison with the control (Table 4). The results showed that increasing the ultrasonic irradiation time from 10 to 20 minutes on the final product packed in polypropylene packages results in the same high degree of sterility (low degree of microbial contamination). A similar effect on the pear jam's microbial contamination was observed when treated with ultraviolet light for 10.15 and 20 minutes in glass containers (Table 4). The strong bactericidal effect of ultrasound (Table 4) occurred because it was not hindered by polypropylene packaging. The use of ultrasound irradiation with a 20 to $100 \mathrm{kHz}$ frequency is connected with the mechanical effect of ultrasound caused by unstable cavitation [70]. This led to a reduction in the final product's bacterial content due to the antibacterial effect of ultrasound [71]. The results (Table 4) showed that regardless of the duration of the ultrasonic exposure to the final product in the glass packages, mesophilic bacteria's development and growth were not inhibited. Applying ultrasound with a frequency of $20 \mathrm{kHz}$ to $100 \mathrm{kHz}$ is an effective method for the destruction of molds and yeasts [72] and acid-resistant Escherichia coli [73]. The data (Table 4) showed that, regardless of the duration of the high-frequency ultrasound exposure, molds and yeasts' development and growth on the final product in the glass packages was inhibited.

\section{Conclusions}

The ultraviolet light treatment of a fruit jam resulted in a lower sucrose content and energy value compared to the samples treated with ultrasonic irradiation. Irradiation of fruit jam from pears with ultraviolet light and ultrasound waves did not significantly affect the concentration of metals, $\mathrm{pH}$, and dry matter content. Ultrasound treatment has a stronger enhancing effect than ultraviolet light on evaluating fruit jam's sensory characteristics, except for hardness, where the opposite effect was observed. The lowest microbial growth level was obtained by treating the final product with ultraviolet light and ultrasound for 10 minutes in polypropylene packaging and 15 minutes in a glass packaging. As a treatment method, the use of ultrasound is recommended due to improved sensory characteristics and microbiological safety when using a cheaper packaging material like polypropylene.

\section{Funding}

This research was funded by the basic research for young scientists and Ph.D. students - 2018, THE MINISTRY OF EDUCATION AND SCIENCE, BULGARIA, grant number KП-06M27/8 (08.12.2018) "Production of low-calorie fruit jam from pears enriched with fibers". 


\section{Acknowledgments}

The authors acknowledge the financial support given by the Ministry of Education and Science, Bulgaria.

\section{Conflicts of Interest}

The authors declare that they have no conflict of interest.

\section{References}

1. Chin, S.T.; Nazimah, S.A.H.; Quek, S.Y.; Che Man, Y.B.; Abdul Rahman, R.; Mat Hashim, D. Changes of volatiles' attribute in durian pulp during freeze- and spray-drying process. LWT - Food Science and Technology 2008, 41, 1899-1905, http://dx.doi.org/10.1016/j.lwt.2008.01.014.

2. Lespinard, A.R.; Bambicha, R.R.; Mascheroni, R.H. Quality parameters assessment in kiwi jam during pasteurization. Modelling and optimization of the thermal process. Food Bioprod. Process. 2012, 90, 799808, http://dx.doi.org/10.1016/j.fbp.2012.03.001

3. Holzwarth, M.; Korhummel, S.; Siekmann, T.; Carle, R.; Kammerer, D.R. Influence of different pectins, process and storage conditions on anthocyanin and colour retention in strawberry jams and spreads. $L W T$ Food Science and Technology 2013, 52, 131-138, http://dx.doi.org/10.1016/j.lwt.2012.05.020.

4. Cheigh, C.-I.; Park, M.-H.; Chung, M.-S.; Shin, J.-K.; Park, Y.-S. Comparison of intense pulsed light- and ultraviolet (UVC)-induced cell damage in Listeria monocytogenes and Escherichia coli O157:H7. Food Control 2012, 25, 654-659, http://dx.doi.org/10.1016/j.foodcont.2011.11.032.

5. Koutchma, T.; Popović, V.; Ros-Polski, V.; Popielarz, A. Effects of Ultraviolet Light and High-Pressure Processing on Quality and Health-Related Constituents of Fresh Juice Products. Comprehensive Reviews in Food Science and Food Safety 2016, 15, 844-867, http://dx.doi.org/10.1111/1541-4337.12214.

6. Csapó, J.; Prokisch, J.; Albert, C.; Sipos, P. Effect of UV light on food quality and safety. Acta Universitatis Sapientiae, Alimentaria 2019, 12, 21-41, http://dx.doi.org/10.2478/ausal-2019-0002.

7. Meléndez-Pizarro, C.O.; Calva-Quintana, A.; Espinoza-Hicks, J.C.; Sánchez-Madrigal, M.Á.; QuinteroRamos, A. Continuous Flow UV-C Irradiation Effects on the Physicochemical Properties of Aloe vera Gel and Pitaya (Stenocereus spp.) Blend. Foods 2020, 9, http://dx.doi.org/10.3390/foods9081068.

8. Bhat, R.; Ameran, S.B.; Voon, H.C.; Karim, A.A.; Tze, L.M. Quality attributes of starfruit (Averrhoa carambola L.) juice treated with ultraviolet radiation. Food Chem. 2011, 127, 641-644, http://dx.doi.org/10.1016/j.foodchem.2011.01.042.

9. Zhang, C.; Trierweiler, B.; Li, W.; Butz, P.; Xu, Y.; Rüfer, C.E.; Ma, Y.; Zhao, X. Comparison of thermal, ultraviolet-c, and high pressure treatments on quality parameters of watermelon juice. Food Chem. 2011, 126, 254-260, http://dx.doi.org/10.1016/j.foodchem.2010.11.013.

10. Pala, Ç.U.; Toklucu, A.K. Effect of UV-C light on anthocyanin content and other quality parameters of pomegranate juice. J. Food Compost. Anal. 2011, 24, 790-795, http://doi.org/10.1016/j.jfca.2011.01.003.

11. Lu, G.; Li, C.; Liu, P. UV inactivation of milk-related microorganisms with a novel electrodeless lamp apparatus. Eur. Food Res. Technol. 2011, 233, 79-87, http://dx.doi.org/10.1007/s00217-011-1498-5.

12. Guerrero-BeltrÉN, J.A.; Barbosa-CÉNovas, G.V. Inactivation of Saccharomyces cerevisiae and Polyphenoloxidase in Mango Nectar Treated with UV Light. J. Food Prot. 2006, 69, 362-368, http://dx.doi.org/10.4315/0362-028X-69.2.362.

13. Usaga, J.; Manns, D.C.; Moraru, C.I.; Worobo, R.W.; Padilla-Zakour, O.I. Ascorbic acid and selected preservatives influence effectiveness of UV treatment of apple juice. LWT 2017, 75, 9-16, http://dx.doi.org/10.1016/j.lwt.2016.08.037.

14. Santhirasegaram, V.; Razali, Z.; George, D.S.; Somasundram, C. Comparison of UV-C treatment and thermal pasteurization on quality of Chokanan mango (Mangifera indica L.) juice. Food Bioprod. Process. 2015, 94, 313-321, http://dx.doi.org/10.1016/j.fbp.2014.03.011.

15. Lavilla, M.; Lasagabaster, A.; Martínez-de-Marañón, I. Impact of Ultraviolet Processing on Food Composition. In Effect of Emerging Processing Methods on the Food Quality: Advantages and Challenges, Roohinejad, S., Koubaa, M., Greiner, R., Mallikarjunan, K., Eds. Springer International Publishing: Cham, 2019, https://doi.org/10.1007/978-3-030-18191-8. 
16. Ricciardi, E.F.; Pedros-Garrido, S.; Papoutsis, K.; Lyng, J.G.; Conte, A.; Del Nobile, M.A. Novel Technologies for Preserving Ricotta Cheese: Effects of Ultraviolet and Near-Ultraviolet-Visible Light. Foods 2020, 9, http://dx.doi.org/10.3390/foods9050580.

17. Alabdali, T.A.M.; Icyer, N.C.; Ucak Ozkaya, G.; Durak, M.Z. Effect of Stand-Alone and Combined Ultraviolet and Ultrasound Treatments on Physicochemical and Microbial Characteristics of Pomegranate Juice. Applied Sciences 2020, 10, https://doi.org/10.3390/app10165458.

18. Ngo, T.H.D.; Ngo, D.N. Effects of low-frequency ultrasound on heterogenous deacetylation of chitin. Int. J. Biol. Macromol. 2017, 104, 1604-1610, http://dx.doi.org/10.1016/j.ijbiomac.2017.03.117.

19. Silventoinen, P.; Sozer, N. Impact of Ultrasound Treatment and pH-Shifting on Physicochemical Properties of Protein-Enriched Barley Fraction and Barley Protein Isolate. Foods 2020, 9 , http://dx.doi.org/10.3390/foods9081055.

20. Etzbach, L.; Pfeiffer, A.; Schieber, A.; Weber, F. Effects of thermal pasteurization and ultrasound treatment on the peroxidase activity, carotenoid composition, and physicochemical properties of goldenberry (Physalis peruviana L.) puree. LWT 2019, 100, 69-74, http://dx.doi.org/10.1016/j.lwt.2018.10.032.

21. YikmiŞ, S. Effect of ultrasound on different quality parameters of functional sirkencubin syrup. Food Science and Technology 2020, 40, 258-265, http://dx.doi.org/10.1590/fst.40218.

22. Fonteles, T.V.; Costa, M.G.M.; de Jesus, A.L.T.; de Miranda, M.R.A.; Fernandes, F.A.N.; Rodrigues, S. Power ultrasound processing of cantaloupe melon juice: Effects on quality parameters. Food Res. Int. 2012, 48, 41-48, http://dx.doi.org/10.1016/j.foodres.2012.02.013.

23. Zou, Y.; Jiang, A. Effect of ultrasound treatment on quality and microbial load of carrot juice. Food Science and Technology 2016, 36, 111-115, http://dx.doi.org/10.1590/1678-457X.0061.

24. O'Shea, N.; Arendt, E.K.; Gallagher, E. Dietary fibre and phytochemical characteristics of fruit and vegetable by-products and their recent applications as novel ingredients in food products. Innov. Food Sci. Emerg. Technol. 2012, 16, 1-10, http://dx.doi.org/10.1016/j.ifset.2012.06.002.

25. Fuller, S.; Beck, E.; Salman, H.; Tapsell, L. New Horizons for the Study of Dietary Fiber and Health: A Review. Plant Foods Hum. Nutr. 2016, 71, 1-12, http://dx.doi.org/10.1007/s11130-016-0529-6.

26. Banaś, A.; Korus, A.; Korus, J. Texture, Color, and Sensory Features of Low-Sugar Gooseberry Jams Enriched with Plant Ingredients with Prohealth Properties. J. Food Qual. 2018, 2018, 1646894, http://dx.doi.org/10.1155/2018/1646894.

27. Regulation (EC) No 1924/2006 of the European Parliament and of the Council of 20 December 2006 on nutrition and health claims made on foods. Available online: https://eur-lex.europa.eu/legalcontent/en/ALL/?uri=CELEX\%3A32006R1924.

28. Manev, Z.; Petkova N. Investigation of the Influence of Calcium Salts and Gelling Time on the Structural Mechanical Properties of Fruit Jam. Bulletin UASVM Food Science and Technology, 2020, 77, 88-93. http://dx.doi.org/10.15835/buasvmcn-fst: 2020.0010

29. ISO 750:1998(E). Fruit and vegetable products - Determination of titratable acidity. Geneva, Switzerland: International Organization for Standardization (ISO), 1998. Available online: https://www.iso.org/standard/22569.html.

30. Dimkova, S.; Ivanova, D.; Stefanova, B.; Marinova, N.; Todorova, S. Chemical and technological characteristic of plum cultivars of prunus domestica 1. Bulgarian Journal of Agricultural Science 2018, 24.

31. Ognyanov, M.; Petkova, N. Phytochemical characteristics and in vitro antioxidant activity of fresh, dried and processed fruits of Cornelian cherries (Cornus mas L.). Bul. Chem. Comm., 2018, 50, 302-307, https://doi.org/10.13140/RG.2.2.36024.44805.

32. AOAC Official Method 940.26 Ash of Fruits and Fruit Products. Gaithersburg, MD, USA, AOAC International, 2007b. Available online: http://www.eoma.aoac.org/methods/info.asp?ID=15176.

33. Petkova, N. Characterization of Inulin from black salsify (Scorzonera hisppanica L.) for food and pharmaceutical purposes. Asian journal of Pharmaceutical and Clinical research 2018, 11, 221-225, https://doi.org/10.22159/ajpcr.2018.v11i12.28262.

34. ВNS Bulgarian State Standard БДС ISО 1871:2014. Food and feed products - General guidelines for the determination of nitrogen by the Kjeldahl method. Available online: https://bdsbg.org/bg/project/show/bds:proj:88389.

35. Regulation (EU) No 1169/2011. Available online: https://eur-lex.europa.eu/legalcontent/EN/ALL/?uri=CELEX\%3A32011R1169.

36. ISO 11885:2007. Water quality — Determination of selected elements by inductively coupled plasma optical emission spectrometry (ICP-OES). Available online: https://www.iso.org/standard/36250.html. 
37. Karabagias, V.K.; Karabagias, I.K.; Gatzias, I.; Riganakos, K.A. Characterization of prickly pear juice by means of shelf life, sensory notes, physicochemical parameters and bio-functional properties. J. Food Sci. Technol. 2019, 56, 3646-3659, http://dx.doi.org/10.1007/s13197-019-03797-4.

38. EN ISO 21527-2:2011:Microbiology of food and animal feeding stuffs. Horizontal method for the determination of yeasts and moulds. Part 2: Colony count technique in products with water activity less than or equal to 0.95 . CEN/TC 275, Brussels, Belgium. Available online: https://www.iso.org/standard/38276.html.

39. EN ISO 4833-1:2013: Microbiology of the food chain. Horizontal method for enumeration of microorganisms. Part 1: Colony count at $30^{\circ} \mathrm{C}$ by the pour plate technique. CEN/TC 275, Brussels, Belgium. Available online: https://www.iso.org/standard/53728.html.

40. Mohd-Hanif, H.; Shamsudin, R.; Adzahan, N.M. UVC dosage effects on the physico-chemical properties of lime (Citrus aurantifolia) juice. Food Sci. Biotechnol. 2016, 25, 63-67, http://dx.doi.org/10.1007/s10068-0160099-2.

41. Sharma, H.K.; Kaur, J.; Sarkar, B.C.; Singh, C.; Singh, B. Effect of pretreatment conditions on physicochemical parameters of carrot juice. Int. J. Food Sci. Tech. 2009, 44, 1-9. http://dx.doi.org/10.1111/j.1365-2621.2006.01462.x.

42. Amiri, A.; Sharifian, P.; Soltanizadeh, N. Application of ultrasound treatment for improving the physicochemical, functional and rheological properties of myofibrillar proteins. Int. J. Biol. Macromol. 2018, 111, 139-147, http://dx.doi.org/10.1016/j.ijbiomac.2017.12.167.

43. Ikegaya, A.; Toyoizumi, T.; Ohba, S.; Nakajima, T.; Kawata, T.; Ito, S.; Arai, E. Effects of distribution of sugars and organic acids on the taste of strawberries. Food Science \& Nutrition 2019, 7, 2419-2426, http://dx.doi.org/10.1002/fsn3.1109.

44. Teixeira, F.; Santos, B.A.; Nunes, G.; Soares, J.M.; Amaral, L.A.; Souza, G.H.; Resende, J.T.; Menegassi, B.; Rafacho, B.P.; Schwarz, K.; Santos, E.F.; Novello, D. Addition of Orange Peel in Orange Jam: Evaluation of Sensory, Physicochemical, and Nutritional Characteristics. Molecules 2020, 25, http://dx.doi.org/10.3390/molecules25071670.

45. Gómez-López, V.M.; Buitrago, M.E.; Martínez-Yepez, A. Effect of ultrasonication on sensory and chemical stability of passion fruit juice during refrigerated storage. Emirates Journal of Food and Agriculture 2018, 85-89, http://dx.doi.org/10.9755/ejfa.2018.v30.i1.1587.

46. Wiktor, A.; Sledz, M.; Nowacka, M.; Rybak, K.; Witrowa-Rajchert, D. The influence of immersion and contact ultrasound treatment on selected properties of the apple tissue. Applied Acoustics 2016, 103, 136-142, http://dx.doi.org/10.1016/j.apacoust.2015.05.001.

47. Kántor, A.; Alexa, L.; Kovács, B.; Czipa, N. DETERMINATION OF NUTRITIONAL PARAMETERS OF COMMERCIAL AND HOME-MADE JAMS. Journal of Microbiology, Biotechnology and Food Sciences 2021, 2021, 407-411, http://dx.doi.org/10.15414/jmbfs.2017.7.4.407-411.

48. Gogo, E.O.; Opiyo, A.M.; Hassenberg, K.; Ulrichs, C.; Huyskens-Keil, S. Postharvest UV-C treatment for extending shelf life and improving nutritional quality of African indigenous leafy vegetables. Postharvest Biol. Technol. 2017, 129, 107-117, http://dx.doi.org/10.1016/j.postharvbio.2017.03.019.

49. Hemmaty, S.; Moallemi, N.; Naseri, L. Efecto de la radicación UV-C y del agua caliente en el contenido de calcio y calidad poscosecha de manzanas.[Effect of UV-C radication and hot water on the calcium content and postharvest quality of apples]. Spanish journal of agricultural research (España).(Dic 2007, 5, 559-568, http://doi.org/10.5424/sjar/2007054-277.

50. Farida, B.; Arkoub, L.; Boudraa, A.T.; Bellaagoune, S. Physicochemical characteristics and phytochemical content of jam made from melon (Cucumis melo). International Food Research Journal 2018, 25, $133-141$.

51. Guevara, M.; Tejera, E.; Granda-Albuja, M.G.; Iturralde, G.; Chisaguano-Tonato, M.; Granda-Albuja, S.; Jaramillo-Vivanco, T.; Giampieri, F.; Battino, M.; Alvarez-Suarez, J.M. Chemical Composition and Antioxidant Activity of the Main Fruits Consumed in the Western Coastal Region of Ecuador as a Source of Health-Promoting Compounds. Antioxidants 2019, 8, http://dx.doi.org/10.3390/antiox8090387

52. Hudina, M.; Stampar, F.; Orazem, P.; Petkovsek, M.M.; Veberic, R. Phenolic compounds profile, carbohydrates and external fruit quality of the 'Concorde' pear (Pyrus communis L.) after bagging. Canadian Journal of Plant Science 2011, 92, 67-75, http://dx.doi.org/10.4141/cjps2011-095.

53. Falguera, V.; Garvín, A.; Garza, S.; Pagán, J.; Ibarz, A. Effect of UV-Vis Photochemical Processing on Pear Juices from Six Different Varieties. Food and Bioprocess Technology 2014, 7, 84-92, http://dx.doi.org/10.1007/s11947-013-1069-9. 
54. Abdul Karim Shah, N.N.; Shamsudin, R.; Abdul Rahman, R.; Adzahan, N.M. Fruit Juice Production Using Ultraviolet Pasteurization: A Review. Beverages 2016, 2, http://dx.doi.org/10.3390/beverages2030022.

55. Saeeduddin, M.; Abid, M.; Jabbar, S.; Hu, B.; Hashim, M.M.; Khan, M.A.; Xie, M.; Wu, T.; Zeng, X. Physicochemical parameters, bioactive compounds and microbial quality of sonicated pear juice. Int. J. Food Sci. Tech. 2016, 51, 1552-1559, http://dx.doi.org/10.1111/ijfs.13124.

56. Akagić, A.; Oras, A.V.; Oručević Žuljević, S.; Spaho, N.; Drkenda, P.; Bijedić, A.; Memić, S.; Hudina, M. Geographic Variability of Sugars and Organic Acids in Selected Wild Fruit Species. Foods 2020, 9 , http://dx.doi.org/10.3390/foods9040462.

57. Abid, M.; Jabbar, S.; Wu, T.; Hashim, M.M.; Hu, B.; Lei, S.; Zeng, X. Sonication enhances polyphenolic compounds, sugars, carotenoids and mineral elements of apple juice. Ultrason. Sonochem. 2014, 21, 93-97, http://dx.doi.org/10.1016/j.ultsonch.2013.06.002.

58. Yadav, A.; Gulia, G.; Yadav, B. Development Of Mulberry Enriched Fruit Jam By Replacing Refined Sugar With Mulberry Fruit. Intenational Journal of Scientific \& Technology Research 2020, 9, 4079-4083.

59. Okudu, H.O.; Umoh, E.J.; Ojinnaka, M.C.; Chianakwalam, O.F. Nutritional, functional and sensory attributes of jam from velvet tamarind pulp. African Journal of Food Science 2017, 11, 44-49, http://dx.doi.org/10.5897/AJFS2016.1496.

60. Asema, S.U.K.; Parveen, N. Study of heavy metal content by AAS in a variety of flavours of jam samples and its physicochemical characterization. Int. J. Sci. Res. Sci. Eng. Technol 2018, 4, 1259-1261.

61. Mahdi, Z.E. Chemical, Sensory and Microbiological Assessment of Some Local and Imported Jam in the Egyptian Market. Ann. Agric. Sci., Moshtohor 2019, 57, 405-418, http://dx.doi.org/10.21608/assjm.2019.44299.

62. Sallam, A.; El-Beltagy, A.; El-Bedewy, A. Preparation of new jams recipes using some un traditional agricultural resources. Ann. Agric. Sci. Moshto. 2016, 54, 601-608.

63. Garcia Loredo, A.B.; Guerrero, S.N.; Alzamora, S.M. Impact of combined ascorbic acid/CaCl2, hydrogen peroxide and ultraviolet light treatments on structure, rheological properties and texture of fresh-cut pear (William var.). J. Food Eng. 2013, 114, 164-173, http://dx.doi.org/10.1016/j.jfoodeng.2012.08.017.

64. Sulaiman, A.; Soo, M.J.; Farid, M.; Silva, F.V.M. Thermosonication for polyphenoloxidase inactivation in fruits: Modeling the ultrasound and thermal kinetics in pear, apple and strawberry purees at different temperatures. J. Food Eng. 2015, 165, 133-140, http://dx.doi.org/10.1016/j.jfoodeng.2015.06.020.

65. Koca, N.; Urgu, M.; Saatli, T.E. Ultraviolet light applications in dairy processing. Technological Approaches for Novel Applications in Dairy Processing 2018, 1, http://dx.doi.org/10.5772/intechopen.74291.

66. Pereira, R.V.; Bicalho, M.L.; Machado, V.S.; Lima, S.; Teixeira, A.G.; Warnick, L.D.; Bicalho, R.C. Evaluation of the effects of ultraviolet light on bacterial contaminants inoculated into whole milk and colostrum, and on colostrum immunoglobulin G. J. Dairy Sci. 2014, 97, 2866-2875, http://dx.doi.org/10.3168/jds.2013-7601.

67. Ma, L.; Zhang, M.; Bhandari, B.; Gao, Z. Recent developments in novel shelf life extension technologies of fresh-cut fruits and vegetables. Trends Food Sci. Technol. 2017, 64, 23-38, http://dx.doi.org/10.1016/j.tifs.2017.03.005.

68. Gayán, E.; Condón, S.; Álvarez, I. Biological Aspects in Food Preservation by Ultraviolet Light: a Review. Food and Bioprocess Technology 2014, 7, 1-20, http://dx.doi.org/10.1007/s11947-013-1168-7.

69. Hakguder Taze, B.; Unluturk, S. Effect of postharvest UV-C treatment on the microbial quality of 'Şalak' apricot. Scientia Horticulturae 2018, 233, 370-377, https://doi.org/10.1016/j.scienta.2018.02.012.

70. Laborde, J.L.; Bouyer, C.; Caltagirone, J.P.; Gérard, A. Acoustic bubble cavitation at low frequencies. Ultrasonics 1998, 36, 589-594, http://dx.doi.org/10.1016/S0041-624X(97)00105-4.

71. Gallo, M.; Ferrara, L.; Naviglio, D. Application of Ultrasound in Food Science and Technology: A Perspective. Foods 2018, 7, http://dx.doi.org/10.3390/foods7100164.

72. Chen, L.; Bi, X.; Cao, X.; Liu, L.; Che, Z. Effects of high-power ultrasound on microflora, enzymes and some quality attributes of a strawberry drink. J. Sci. Food Agric. 2018, 98, 5378-5385, http://dx.doi.org/10.1002/jsfa.9079.

73. Yildiz, S.; Pokhrel, P.R.; Unluturk, S.; Barbosa-Cánovas, G.V. Identification of equivalent processing conditions for pasteurization of strawberry juice by high pressure, ultrasound, and pulsed electric fields processing. Innov. Food Sci. Emerg. Technol. 2019, 57, 102195 , http://dx.doi.org/10.1016/j.ifset.2019.102195. 